\title{
円柱群を用いた新たな消波工の開発に関する実験的研究
}

\section{An Experimental Study on Development of a Break Water Using Circular Cylinder Array}

\author{
高田浩太郎 ${ }^{1} \cdot$ 重松孝昌 $^{2} \cdot$ 加藤健司 $^{3} \cdot$ 脇本辰郎 $^{4} \cdot$ 吉岡真弥 ${ }^{5}$
}

Kotaro TAKATA, Takaaki SHIGEMATSU, Kenji KATOH, Tatsuro WAKIMOTO and Shinya YOSHIOKA

\begin{abstract}
In this study, a new type breakwater with a submerged circular cylinder array was developed. Laboratory experiments were carried out for investigation on effect of the height of submerged circular cylinder array on wave absorber function. Experimental results were compared with theoretical solutions. For the other type of a new breakwater with rotatable circular cylinder array, the characteristics of wave absorption were investigated.
\end{abstract}

\section{1.はじめに}

国土交通白書（国土交通省，2012）によれば，建設後 50 年以上経過する港湾岸壁は今後急増し, 2020 年には約 $25 \%, 2030$ 年には約 $53 \%$ に及ぶ. 今後，これらの老朽化 する施設を維持・更新する際には，より優れた機能を有 する構造物への更新も視野に入れた検討が成されること であろう。

Jarlan（1961）によって直立式の消波構造物が提案されて 以来, 特に, 我が国においては, 港湾海域の有効利用や構 造物に対する経済性の観点から, 直立式消波構造物に関す る活発な研究が遂行されてきた. 矩形空を前面板に有する もの（Terrettら，1968）, 曲面で構成される前面壁を有する もの（谷本ら，1980), 前面板の柱体の寸法が水深方向に変 化するもの（角野ら，1988）, 二重円筒ケーソン（谷本ら, 1988）などは, その代表的なものとして挙げられる.これ らの構造物の消波機能は, 基本的には前面板を水粒子が通 過する際に渦流が形成され, この渦運動によって流体の運 動エネルギーが消費されることによる，渦流の形成は，波 の条件として相対水深, 入射波の波形勾配, 構造条件とし てスリット壁の開口比, 遊水室幅, スリット形状など, 多 くのパラメータによって変化し, これらの条件に応じて固 有の消波対象波が存在する. その消波機能については理論 的にも実験的にも多くの研究が成されており, その機能評 価手法はほほ確立されていると言える。しかし，これまで の消波工の多くは前面壁が全水深にわたって一様な形状を 有しており，前面壁が没水構造を有するもの，また，前面

$\begin{array}{lll}1 \text { 学生会員 } & \begin{array}{l}\text { 大阪市立大学 大学院工学研究科都市系 } \\ 2 \text { 正会員 }\end{array} \\ 3 & \text { 博 (工) } \begin{array}{l}\text { 大阪市立大学教授 大学院工学研究科都 } \\ \text { 市系専攻 }\end{array} \\ \text { 大阪市立大学教授 大学院工学研究科 } \\ \text { 機械物理系専攻 } \\ \text { 大阪市立大学准教授 大学院工学研究科 } \\ \text { 機械物理系専攻 } \\ \text { 大阪市立大学准教授 大学院工学研究科 } \\ \text { 機械物理系専攻 }\end{array}$

壁が可動な構造を有するものに対する研究はほとんどない. そこで，本研究では，まず，前面壁が没水構造を有す る消波構造物を対象として, その消波機能について実験 的に検討する. その後, 得られた知見に基づいて, 柱体 が波エネルギーによって回転する場合についても, 同様 の検討を行う。これらを通じて, 新たな消波構造物を模 索することを目的とする.

\section{2. スリット構造物の反射率に関する理論解}

角野ら（1986a）は, 角柱や円柱などの柱体列からなる スリット構造物（図-1）を対象として，これに波が入射す る場合の反射あるいは透過特性を, 漸近展開接合法 (Method of matched Asymptotic Expansion) を適用して, 理論的に求めている. 柱体の境界条件を厳密に満足する 柱体近傍のポテンシャル流動を解析するために, 柱体断 面形状のみによって決定される純理論定数 $C$ (blockage coefficient) 導入したこと, 流体がスリットを通過する際 のエネルギー損失を見積もるために, 実部にblockage coefficientを持つ複素 blockage coefficient $\left(C_{1}=C+i C_{f}\right)$ を導入 したことに独創性がある. 円柱列に対する blockage coefficient： $C$ は, 次式で求められる.

$$
\frac{C}{D}=\frac{\pi}{8}\left(1-\frac{2 a}{D}\right)^{2}\left(1+C_{a}\right)
$$

ここに, $D$ は柱体中心間距離, $2 a$ はスリット幅を表し, $2 a / D$ は開口率を表す. また, $C_{a}$ は付加質量係数で, 次式 でその第 1 近似を示すように開口率 $2 a / D$ に対して一意的 に与えられる。

$$
C_{a}=\frac{12+\pi^{2}(1-2 a / D)^{2}}{12-\pi^{2}(1-2 a / D)^{2}}
$$

さらに, 角野ら (1986a，1986b) は, 柱体列の背面に不透過 壁を有する縦スリット直立消波工についても同理論を適用し て, 直立消波工の反射率 $K_{r}$ を次式のように導いている.

$$
K_{r}=\sqrt{1-\frac{2 k C_{f} C_{b}}{k^{2}\left(C^{2}+C_{f}^{2}\right) C_{b}-2 k C \sin 2 k \ell+1+k C_{f} C_{b}}}
$$




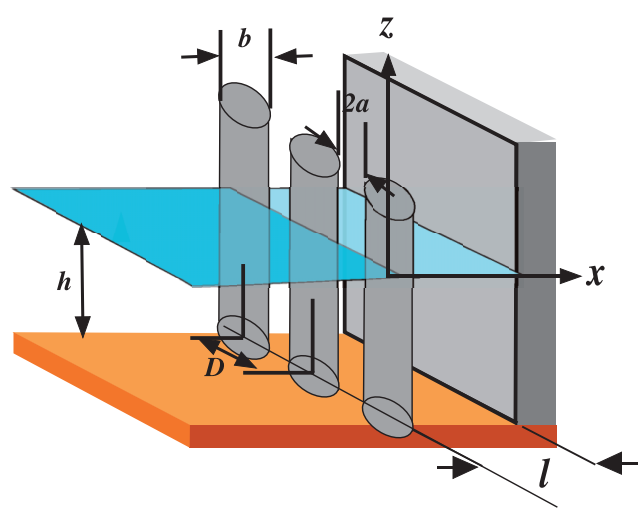

図-1＼cjkstart縦スリット消波工の諸元

$C_{b}=2(1-\cos 2 k \ell)$

ここに, $k=2 \pi / L$ : 波数 ( $L$ : 波長), $\ell$ は消波室幅であ る. また, $C_{f}$ は以下の超越方程式を解いて求められる.

$$
\frac{C_{f}}{D}=\frac{4\left(\sinh ^{2}[k h]+3\right)}{9 \pi(2 a / D)^{2}(\sinh [2 k h]+2 k h)} \gamma \frac{H}{L} \frac{L}{D} f
$$

ここに, $h$ は水深を表わし, $\gamma$ は次式で求められる.

$$
\gamma=\sqrt{\frac{C_{b}}{k^{2}\left(C^{2}+C_{f}^{2}\right) C_{b}-2 k C \sin 2 k \ell+1+k C_{f} C_{b}}} \cdots
$$

式 (5) を計算する際，不透過壁前面の柱体列が円柱の場合 には，損失係数 $f$ は 0.75 を用いる（角野ら，1993）。さら に，スリット部におけるエネルギー損失に影響を及ぼす スリット通過水粒子速度振幅 $V_{\text {max }}$ は，入射波の水平水粒 子速度振幅 $u_{\max }$ を用いて次式で求められる.

$$
\frac{V_{\max }}{u_{\max }}=\frac{\gamma}{2 a / D}
$$

本研究では, 実験によって検証されている上記の理論 解を用い，前面壁を形成する円柱列の高さが反射率に及 ぼす影響を，さらには，円柱列が波浪によって回転する 場合の反射率について検討する。

\section{3. 実験概要}

実験は，図-2に示すような，大阪市立大学水理実験場 の長さ $20 \mathrm{~m}$, 幅 $0.5 \mathrm{~m}$, 高さ $0.6 \mathrm{~m}$ の二次元造波水路を用 いて，水深 $h$ を $0.40 \mathrm{~m}$ で一定として行った。造波板より約 $18 \mathrm{~m}$ 離れた位置に消波工の模型を設置した．消波工の模型 は，不透過壁からその中心軸までの距離（遊水室幅）が $\ell$ だけ離れた位置に直径 $\Phi=0.09 \mathrm{~m}$ の塩化ビニル製の円柱 5

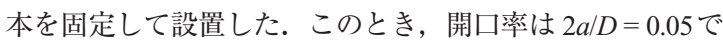
あった． 円柱高さ $H_{w}$ を $H_{w} / h=1.075,0.825,0.525,0.325$ と変えて実験を行った（図-3）. 模型から約 $3.5 \mathrm{~m}$ 沖側に 容量式波高計2本を設置して $100 \mathrm{~Hz}$ で水位変動の時系列デ ー夕を収集し，入・反射波分離推定法（合田ら，1976）に より反射率を求めた。作用波は，周期 $T=0.6 \sim 1.8 \mathrm{~s}$ ，波形 勾配 $H / L=0.01 \sim 0.03$ の規則波とした（表-1，表-2参照）.

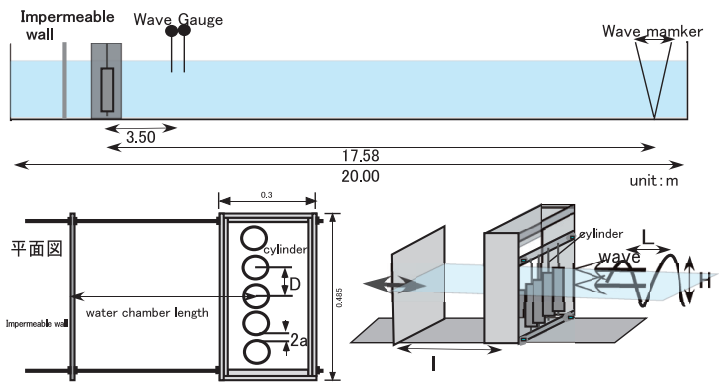

図-2 実験模型
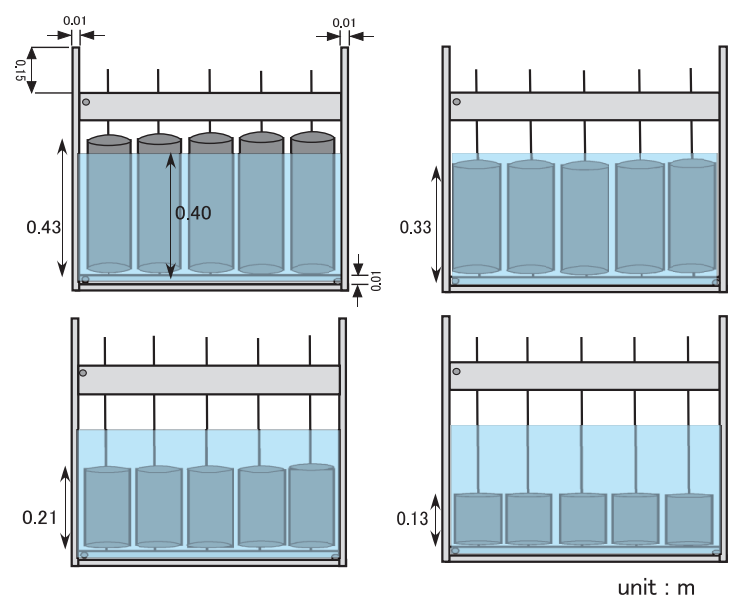

図-3 没水型円柱を前面壁に持つ消波工

得られた反射率の実験值は角野らによる理論解と比較し, 実験の妥当性とともに円柱高さが消波効果に及ぼす影響 について検討した.

さらに，前面壁を構成する円柱が波作用時に自由に回 転する構造（回転円柱型）としたうえで，同様の実験を 行い，反射率を測定した。このとき円柱は，重松ら（2011） を参考にして，図-4のような 2 枚の円弧で構成される羽 根を有する構造とした．その径は $\Phi=0.084 \mathrm{~m}$ で， $2 a / D=$ 0.11 である. 回転円柱の高さは, 固定円柱の結果を参照し て $H_{w}=0.33 \mathrm{~m}$ とした. 水流の方向によらず一定方向に回 転する性質を持たせた。隣接する円柱の回転方向が互い に逆方向になるようにして，回転円柱間に水流がスムー ズに流れ込むようにした。このとき, 円柱が回転するこ とによる反射率への影響は，水車の回転性能に依存する と推測されるので, Perma-Tork HC01-1（日本創販（株） 社製）を用いて負荷トルクを与えた(図-5下図)。円柱の 回転速度は，その円周近傍に一定間隔で孔を開けた回転 盤（図-5上図）を円柱上部に取り付け，光電センサを用 いて回転速度を計測した。波作用時には 5 本の円柱の回転 速度がほぼ同速度となっていることを確認したうえで，実 験を行った. 回転円柱間の水粒子速度の測定には電磁流 


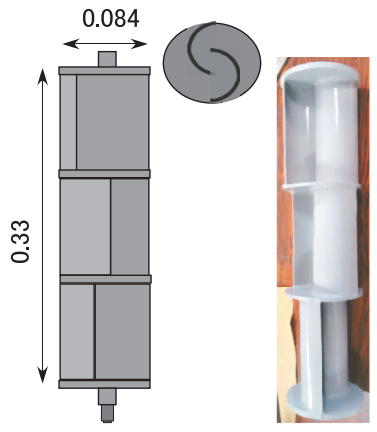

図-4 回転型円柱
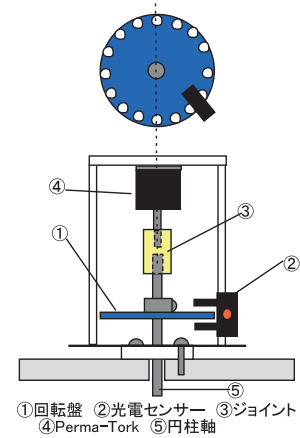

図-5 回転数計測システム

表-1 実験条件および結果 $(\ell=0.20 \mathrm{~m})$

\begin{tabular}{|c|c|c|c|c|c|}
\hline$H_{w} / h$ & $T(\mathrm{~s})$ & $\ell / L$ & $H(\mathrm{~m})$ & $H / L$ & $K_{r}$ \\
\hline \multirow{10}{*}{1.075} & 0.819 & 0.194 & 0.008 & 0.008 & 1.000 \\
\hline & 0.870 & 0.174 & 0.011 & 0.010 & 0.870 \\
\hline & 0.975 & 0.142 & 0.017 & 0.012 & 0.812 \\
\hline & 1.024 & 0.131 & 0.016 & 0.010 & 0.723 \\
\hline & 1.024 & 0.131 & 0.016 & 0.010 & 0.723 \\
\hline & 1.205 & 0.103 & 0.016 & 0.008 & 0.570 \\
\hline & 1.200 & 0.103 & 0.017 & 0.009 & 0.544 \\
\hline & 1.463 & 0.079 & 0.026 & 0.010 & 0.480 \\
\hline & 1.707 & 0.065 & 0.033 & 0.011 & 0.574 \\
\hline & 1.862 & 0.059 & 0.033 & 0.010 & 0.563 \\
\hline \multirow{5}{*}{0.825} & 0.890 & 0.167 & 0.013 & 0.011 & 0.826 \\
\hline & 1.078 & 0.121 & 0.020 & 0.012 & 0.445 \\
\hline & 1.280 & 0.094 & 0.021 & 0.010 & 0.411 \\
\hline & 1.460 & 0.079 & 0.025 & 0.010 & 0.531 \\
\hline & 1.862 & 0.059 & 0.032 & 0.010 & 0.716 \\
\hline \multirow{9}{*}{0.525} & 0.683 & 0.275 & 0.008 & 0.011 & 1.000 \\
\hline & 0.731 & 0.241 & 0.006 & 0.008 & 1.000 \\
\hline & 0.788 & 0.213 & 0.007 & 0.008 & 1.000 \\
\hline & 0.890 & 0.167 & 0.011 & 0.009 & 0.890 \\
\hline & 0.975 & 0.142 & 0.013 & 0.009 & 0.769 \\
\hline & 1.024 & 0.131 & 0.016 & 0.011 & 0.854 \\
\hline & 1.130 & 0.113 & 0.019 & 0.011 & 0.798 \\
\hline & 1.280 & 0.094 & 0.023 & 0.011 & 0.777 \\
\hline & 1.463 & 0.079 & 0.020 & 0.008 & 0.784 \\
\hline \multirow{15}{*}{0.325} & 0.731 & 0.241 & 0.009 & 0.011 & 1.000 \\
\hline & 0.731 & 0.241 & 0.007 & 0.008 & 1.000 \\
\hline & 0.819 & 0.194 & 0.009 & 0.009 & 0.972 \\
\hline & 0.931 & 0.154 & 0.014 & 0.011 & 0.979 \\
\hline & 0.931 & 0.154 & 0.011 & 0.009 & 0.860 \\
\hline & 1.024 & 0.131 & 0.013 & 0.009 & 0.912 \\
\hline & 1.024 & 0.131 & 0.018 & 0.012 & 0.917 \\
\hline & 1.024 & 0.131 & 0.014 & 0.009 & 0.854 \\
\hline & 1.078 & 0.121 & 0.017 & 0.010 & 0.843 \\
\hline & 1.205 & 0.103 & 0.017 & 0.009 & 0.926 \\
\hline & 1.200 & 0.103 & 0.018 & 0.009 & 0.882 \\
\hline & 1.365 & 0.086 & 0.022 & 0.010 & 0.858 \\
\hline & 1.463 & 0.079 & 0.028 & 0.011 & 0.833 \\
\hline & 1.575 & 0.072 & 0.033 & 0.012 & 0.913 \\
\hline & 1.707 & 0.065 & 0.026 & 0.009 & 0.913 \\
\hline
\end{tabular}

速計（アレック電子株式会社 ）を使用し，そのセンサー 部は常に静水面下 $0.27 \mathrm{~m}$, 円柱中心軸から $0.42 \mathrm{~cm}$ 沖側に 設置して测定した。

\section{4. 実験結果}

\section{(1) 固定円柱}

固定円柱型消波工の反射率の実験結果を, 表-1, 表-2に示す.

図-6および図-7は，遊水室幅が $\ell=0.20,0.38 \mathrm{~m}$ の場合に ついて, 固定円柱の高さ $H_{w}$ が反射率 $K r$ に及ぼす影響を 相対遊水室幅 $\ell / L$ の関数として表したものである. 図中の 曲線は, 式 (3)より求められる角野ら（1984）の理論解で ある. $H_{w} / h=1.075$ の場合は円柱が水面を常に横切る条件 となっており, 角野らの理論解との整合性が比較的良好 であることが確認される.これらの図からは, $H_{w} / h=0.325$, 0.525 と水深に対して水車の高さが低くなると, 反射率が 高い值を示すこともわかる。これは，スリットを通過す る際に波エネルギーを減衰させるに十分な渦が形成され ないことを意味していると考えられる。しかし， $H_{w} / h=0.825$ の場合には反射率が低下し，特に $\ell=0.38 \mathrm{~m}$ の場合には, 従来型の消波工 $\left(H_{w} / h=1.075\right.$ の場合）より も反射率が大幅に低下することがわかる. 反射率 $K r$ を $H_{w} / h$ の関数として示した図-8および図-9を見ると, いず れの周期の波に対しても， $H_{w} / h=0.82$ の場合に極小值を とることがより明瞭に理解できる.このように $H_{w} / h \simeq$ 0.8 の場合に反射率が低下する理由として, スリット通過

表-2 実験条件および結果 $(\ell=0.38 \mathrm{~m})$

\begin{tabular}{c|c|c|c|c|c}
\hline$H_{w} / h$ & $T(\mathrm{~s})$ & $\ell / L$ & $H(\mathrm{~m})$ & $H / L$ & $K_{r}$ \\
\hline \multirow{5}{*}{1.075} & 0.853 & 0.342 & 0.010 & 0.009 & 0.936 \\
& 1.070 & 0.233 & 0.013 & 0.008 & 0.808 \\
& 1.280 & 0.179 & 0.016 & 0.008 & 0.648 \\
& 1.463 & 0.150 & 0.025 & 0.010 & 0.616 \\
\hline \multirow{7}{*}{0.825} & 0.819 & 0.368 & 0.009 & 0.009 & 1.000 \\
& 0.819 & 0.368 & 0.012 & 0.012 & 1.000 \\
& 0.975 & 0.271 & 0.016 & 0.011 & 0.834 \\
& 1.200 & 0.196 & 0.019 & 0.010 & 0.522 \\
& 1.280 & 0.179 & 0.020 & 0.009 & 0.470 \\
& 1.463 & 0.150 & 0.028 & 0.011 & 0.189 \\
& 1.575 & 0.137 & 0.031 & 0.011 & 0.181 \\
& 1.862 & 0.112 & 0.028 & 0.008 & 0.259 \\
\hline \multirow{7}{*}{0.525} & 0.640 & 0.595 & 0.007 & 0.011 & 0.951 \\
& 1.024 & 0.250 & 0.014 & 0.009 & 0.719 \\
& 1.205 & 0.195 & 0.018 & 0.009 & 0.771 \\
& 1.280 & 0.179 & 0.016 & 0.008 & 0.719 \\
& 1.862 & 0.112 & 0.035 & 0.010 & 0.756 \\
\hline \multirow{7}{*}{0.325} & 1.078 & 0.230 & 0.019 & 0.011 & 0.907 \\
& 1.078 & 0.230 & 0.020 & 0.012 & 0.838 \\
& 1.078 & 0.230 & 0.014 & 0.008 & 0.907 \\
& 1.280 & 0.179 & 0.025 & 0.012 & 0.954 \\
& 1.707 & 0.124 & 0.026 & 0.008 & 0.865 \\
\hline 7
\end{tabular}




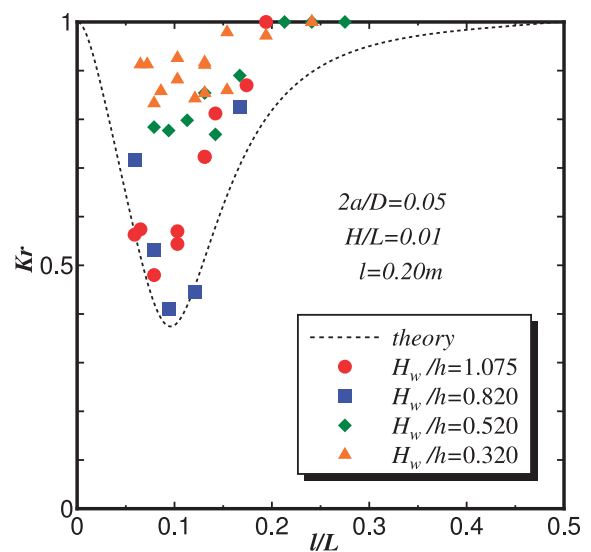

図-6 固定円柱の反射率 $(\ell=0.20 \mathrm{~m})$

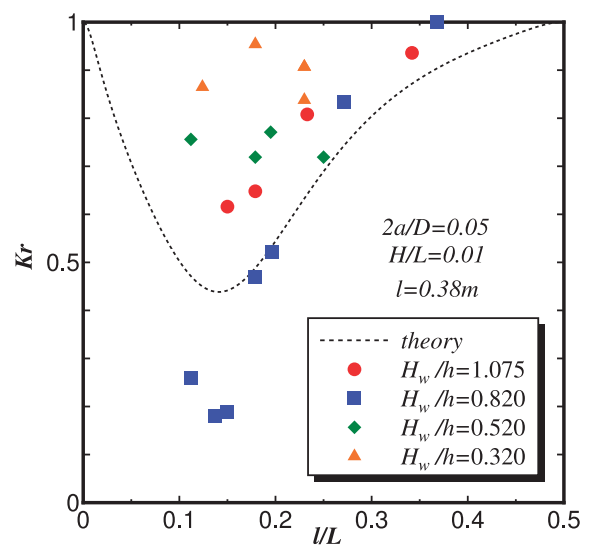

図-7 固定円柱の反射率 $(\ell=0.38 \mathrm{~m})$

流速が増加することによって柱体背後に渦が発生すると ともに，円柱上部を流体が通過することによって強いせ 几断流が発生し，より大きなエネルギー低減が期待でき ることを示していると考えられる。既述のように，スリ ット式直立消波工は強い周期依存性を有しているが，図6〜図-9からは，固定円柱の高さが変化しても反射率が低 下する周期には大きな変化がないことが確認される。

\section{(2) 回転円柱型}

前節の実験で用いた固定円柱とほぼ同じ径を有する回 転円柱を用いてその高さが $H_{s} / h=0.8$ の前面壁とした場 合の反射率 $K_{r}$ を，図-10に相対遊水室幅 $\ell / L$ の関数として 示した，同図の曲線は角野らによる理論解である。回転 円柱を擁する消波工の消波特性は，固定円柱を擁する消 波工と同様に，周期依存性を有する傾向を示すことがわ かる，ただし，反射率は角野らの理論值と比較すると高 くなる.

図-11 は，回転円柱を設置した時の反射率 $K r$ と回転円柱 間通過水粒子速度 $V_{\text {max }}$ を入射波の水平水粒子速度の振幅

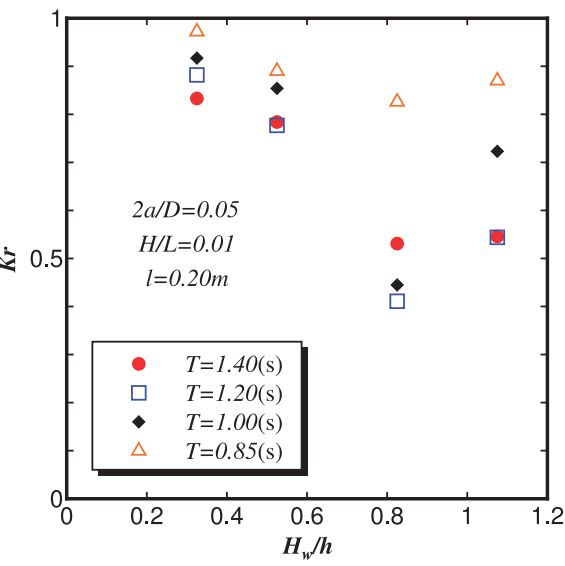

図-8 固定円柱高さと反射率 $(\ell=0.20 \mathrm{~m})$

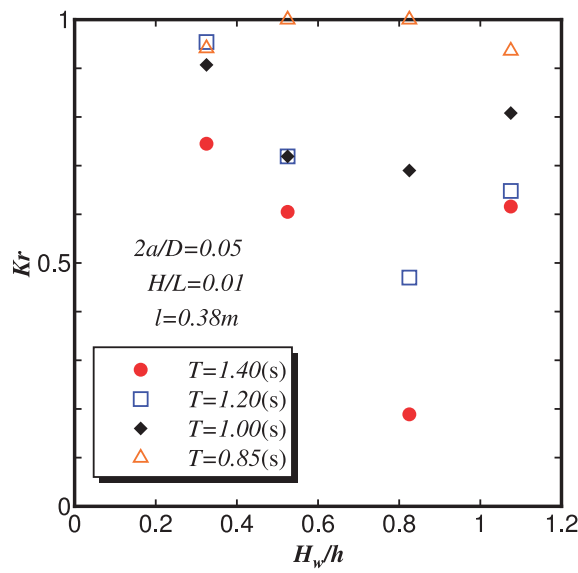

図-9 固定円柱高さと反射率 $(\ell=0.38 \mathrm{~m})$

$u_{\text {max }}$ に対する比を示す. 角野ら (1986a)によれば, $V_{\text {max }} / u_{\text {max }}$ が大きな值を取るときに $K r$ が減少するが，本実験条件では $V_{\text {max }} / u_{\max }$ に大きな変動がなく, その結果として反射率も大き な変動を示していないことがわかる.

回転円柱間を通過する水粒子速度 $V_{\text {max }} / u_{\text {max }}$ と円柱回転 数 $\omega$ との関係を，図-12に示す。同図によれば，水粒子 速度 $V_{\max } / u_{\max }$ が大きい条件では, 円柱の回転数が大きく なる傾向があることが確認される。

表-3は， $T=1.078 \mathrm{~s} ， \ell=0.20 \mathrm{~m}$ の場合について，回転円 柱に作用させる負荷トルク $T_{q}$ が反射率および回転数に及 ぼす影響を示したものである．負荷トルク $T_{q}$ が大きくな るとともに回転数が減少する傾向を示すが，本実験では 反射率に及ぼす影響はほとんど見られない。角野らの理 論によれば，柱体列を擁するスリット式消波工の反射特 性は，blockage coefficient $(C)$ の実部で表現される慣性抵 抗と，Cの虚部で表現される渦流によるエネルギー損失に よって決定される。したがって，本実験結果によれば，回 転円柱の存在は，回転体としての慣性抵抗を形成するも 


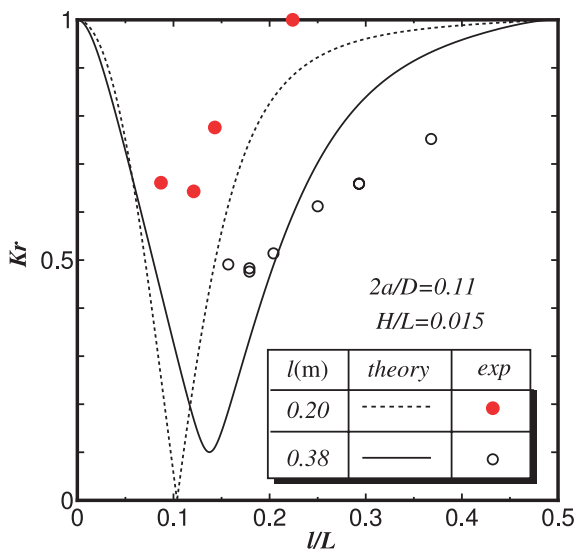

図-10 反射率（回転円柱）

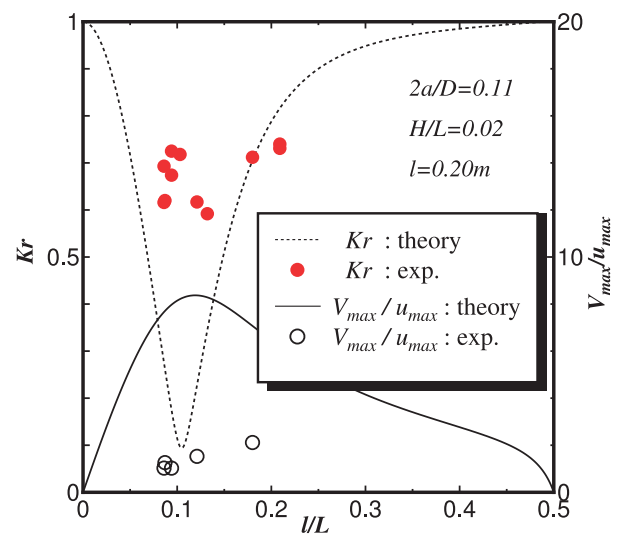

図-11 反射 $K r$ と回転円柱間通過流速

表-3 実験結果 $(\ell=0.20 \mathrm{~m})$

\begin{tabular}{c|c|c|c|c|c}
\hline$T(\mathrm{~s})$ & $\ell / L$ & $H / L$ & $T_{q}\left(\times 10^{-3} \mathrm{~N} \cdot \mathrm{m}\right)$ & $K r$ & $\omega(\mathrm{rpm})$ \\
\hline \multirow{4}{*}{1.078} & \multirow{3}{*}{0.121} & 0.026 & 0.532 & 0.553 & 57.4 \\
& & 0.026 & 1.653 & 0.523 & 50.4 \\
& & 0.025 & 1.866 & 0.521 & 46.2 \\
& & 0.026 & 2.000 & 0.532 & 0.0 \\
\hline
\end{tabular}

のの, 固定円柱と比較すると慣性抵抗が減少し, その結 果として背後に形成する渦流が十分に発達しないのでは ないかと推察される.

\section{5. 結論}

本研究は, 縦スリット消波工の前面壁を構成する柱体 高さを変化させた場合の消波機能について検討するとと もに, 柱体が回転する場合の消波機能についても検討を 行った. 本研究によって得られた結論を要約すると以下 のようである。

1）前面壁の柱体高さは, 従来のような水面を常に横切る 場合よりも水深の $80 \%$ 程度の高さの方が高い消波能

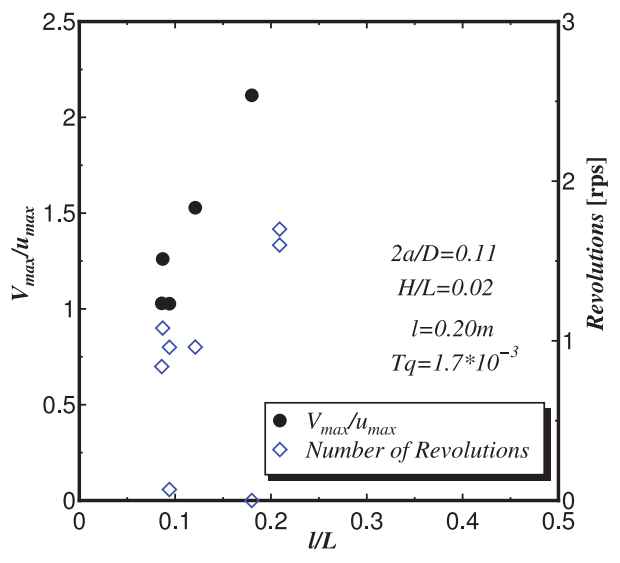

図-12＼cjkstart回転数と通過水粒子速度

力をもつことが明らかになった。このとき，周期依存 性については，従来型の場合との相違はほとんど見ら れない。

2）回転円柱スリットは固定円柱スリットと同様に周期依 存性を持つことがわかった.

3）回転円柱スリットは既往の理論值より反射率が高くな る傾向があることがわかった. 最適構造条件の模索は 今後の課題である.

\section{参 考 文 献}

角野昇八・小田一樹 (1986a) : 任意断面柱体列による波の反射率 および透過率の境界值問題解析，土木学会論文集，第 369 号, II -5, pp. 213-222.

角野昇八·小田一樹・村本哲二・芳田利春 $(1986 \mathrm{~b})$ : 複素係数の blockage coef.導入した漸近展開接合法ースリットにおけるエネルギー損 失量の評価一, 海岸工学論文集, 第33巻, pp. 407-411.

角野昇八·小田一紀・重松孝昌・芳田利春 (1988): 広周波数帯域 にわたって低反射機能を有する直立消波工の開発, 海岸工 学論文集, 第 35 巻, pp. 557-561.

角野昇八・仲田義弘 (1993): エネルギー損失を考慮した多列柱体 列による波の透過と反射に関する研究, 土木学会論文集, 海 岸工学論文集, 第 40 巻, pp. 661-665.

国土交通省 (2012)：国土交通白書 2012平成23年度年次報告, ぎょうせい, $393 \mathrm{p}$.

合田良実・鈴木康正・岸良安治・菊地治 (1976) : 不規則波におけ る入.反射波の分離推定法,港湾技術研究所資料, No.248.

重松孝昌·加藤健司・脇本辰郎・吉岡真弥 (2011)：縦スリッ卜式直 立消波工を利用した波力発電の試み, 海岸工学論文集, 第 67 巻, pp. 1231-1235.

谷本勝利・原中祐人・富田英治 (1980) : 曲面スリットケーソンの水 理特性に関する実験的研究, 港湾技術研究所報告, 第 19 巻, 第 4号, pp. 3-54.

谷本勝利・下迫健一郎 (1988) : 二重円筒ケーソンに働く滑動波力 に対するマウンドの影響, 海岸工学論文集, 第 35 巻, pp. 642-646.

Jarlan, G. L. E. (1961) : A perforated vertical wall breakwater, The Dock \& Harbour Authority, Vol. 41, No. 486, pp. 394-398.

Terrett, F. L., Osorio, J. D. C., and Lean, G. H. (1968) : Model studies of a perforated breakwater, Proc. 11th conf. on Coastal Engng., pp. 1104-1120. 